
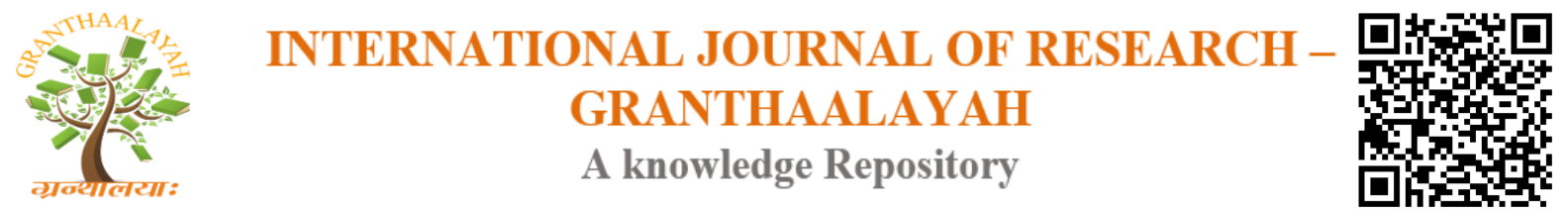

Science

\title{
STUDENT'S ATTITUDE TOWARD LBL VERSUS PBL IN PHARMACOLOGY AT NGMC, BANKE, NEPAL
}

\author{
DB Dhami $^{* 1}$, RS Rathore ${ }^{2}$, VK Bhargava ${ }^{3}$, G Neupane ${ }^{4}$, R.Singh ${ }^{5}$, A.Singh ${ }^{6}$, GJ Shah ${ }^{7}$ \\ 1, 4, 5, 6 Lecturer, Department of Pharmacology, Nepalgunj Medical College (NGMC), Chisapani, \\ Banke, Nepal \\ ${ }^{2,3}$ Professor, Department of Pharmacology, Nepalgunj Medical College (NGMC), Chisapani, \\ Banke, Nepal
}

\begin{abstract}
Background: Reviewing the teaching program at regular intervals and modifications in the teaching methodologies with understanding perceptions and opinions of medical students regarding teaching learning may prove useful in improving the teaching of pharmacology. The objective of the current study was to compare the effectiveness and to assess perception of Problem based learning (PB) and lecturer based learning (LB) in conveying the medical facts in pharmacology.

Methods: A questionnaire was distributed to the students and asked to score each individual statement regarding LBL and PBL. The median total scores and median with interquartile range of individual statements was calculated. A comparison between questions that support LBL or PBL was performed. Student t-test was employed to compare the mean scores of different groups.

Result: Among of one hundred and thirty five (135) students, only one hundred and ten (110) student participated in this study. The individual median score was 37 when compared to possible total score of 55. The total score (mean \pm standard deviation for question 4-7 related to LBL was 2.920 \pm 0.614 and that of the questions 8-11 related to PBL was $3.863 \pm 0.738$. This difference found statistically significant $(\mathrm{p}<0.05)$

Conclusion: Students had more positive perception on PBL compared to the LBL. In PBL, Student analyses the problem through self-directed efforts, solves the given problem by applying knowledge and skills followed by group discussions in adequate infrastructure, trained faculty, well-equipped library and internet facility which is always superior to didactic lectures.
\end{abstract}

Keywords: Pharmacology; Teaching; Lecture-Based Learning (LBL); Problem-Based Learning (PBL).

Cite This Article: DB Dhami, RS Rathore, VK Bhargava, G Neupane, R.Singh, A.Singh, and GJ Shah. (2017). “STUDENT'S ATTITUDE TOWARD LBL VERSUS PBL IN PHARMACOLOGY AT NGMC, BANKE, NEPAL.” International Journal of Research Granthaalayah, 5(9), 244-249. https://doi.org/10.29121/granthaalayah.v5.19.2017.2238. 


\section{Introduction}

The study of drugs, most dynamic and important branch of biological disciplines is medicine. Pharmacology happens to be an integral part that as it includes entire therapeutics and management of various clinical conditions. In Nepal, Pharmacology is taught in the first year and second year of medical sciences course of $4 \frac{1}{2}$ years duration. Teaching in pharmacology uses a combination of lectures, problem based learning, practical and small group discussions ${ }^{1,2}$ Understanding current perceptions and opinions of medical students regarding learning pharmacology may prove useful in improving the teaching of this discipline. Students' feedback would probably reveal whether the betterment of teaching-learning pharmacology subject. It is generally agreed that reviewing the teaching program at regular intervals and modifications in the methodologies of imparting basic knowledge about drugs and drug therapies is a must. ${ }^{3}$

Lecture is a traditional and didactic, most common method of teaching. It helps to provide information to a large number of students at a time however student involvement is minimal. ${ }^{4}$

In PBL, a clinical problem is given to students without prior reading or lecture. The student analyses the problem through self-directed efforts, solves the given problem by applying his knowledge and skills followed later by group discussions acquires knowledge and develops skills. An adequate infrastructure, trained faculty, well-equipped library and internet facility is required for PBL. A tutor is present throughout the session to facilitate the learning process. ${ }^{5}$

According to present view problem based learning is considered superior to the conventional didactic teaching for contextual learning, long term retention of knowledge, development of generic skill and attitudes however still there are no conclusive evidence to indicate usefulness of PBL over LBL. In order to achieve this it is planned to distribute a questionnaire among students to know their opinion about relevance of lecture-based learning (LBL) versus PBL sessions in understanding pharmacology, correlating it with clinical conditions and the effect of these methods on their performance in the examination. The objective of the current study was to compare the effectiveness and to assess perception of PBL and LBL in conveying the medical facts in pharmacology of second year medical students of Nepalgunj Medical College.

\section{Materials and Method}

The study was approved by Institutional Ethics Committee of Nepalgunj Medical College and carried out among second year MBBS Students, who had already experience with PBL and LBL in the College. The students were asked to complete a questionnaire. ${ }^{6.7}$ First part of the questionnaire included demographic data like gender, nationality, and medium of instruction at school. The second part of the questionnaire consisted of 11 statements regarding student's attitude toward LBL versus PBL regarding pharmacology subject.

Questions numbered: 1, 2, 3- were based on general information on lectures and PBL; 4, 5, 6, 7 were based on benefits of lecture over PBL; 8, 9, 10, 11 - were based on benefits of PBL over lecture. The students were asked to score each individual statement using the following key: 1 strongly disagree with the statement, 2 - disagree, 3 - neutral, 4 - agree and 5 - strongly agree with the statement. The students were instructed to use whole numbers only. Thus, data collected 
was analyzed by SPSS and the median total scores and range of individual statements were calculated. Student's t-test was employed for comparison between mean score of questions that support LBL and PBL.

\section{Results}

Among of one hundred and thirty five (135) students, only one hundred and ten (110) student participated in this study. Of these $78.2 \%$ (86) were male and $21.8 \%$ (24) were female. Majority of students were Nepali 59.1\% (65) followed by Indian $40.9 \%$ (45). All of them had English as the medium at school.

The individual median score was 37 when compared to possible total score of 55 . The total score (mean \pm standard deviation for question 4-7 related to LBL was $2.920 \pm 0.614$ and that of the questions $8-11$ related to PBL was $3.863 \pm 0.738$. This difference found statistically significant $(\mathrm{p}<0.05)$. The median scores and interpercentile range of individual statements shown in Table 1 and student perception on general information on LBL and PBL and students perception towards LBL and PBL shown as Table 2,3, and 4 respectively.

Table 1: Median scores and inter-percentile range for individual statements

\begin{tabular}{|l|l|}
\hline \multicolumn{1}{|c|}{ Statements } & \multicolumn{1}{|c|}{$\begin{array}{c}\text { Median } \\
\text { (inter-percentile range) }\end{array}$} \\
\hline $\begin{array}{l}\text { Lecture is essential before PBL for understanding particular topic. } \\
\text { Number of lectures and PBL in the current curriculum is appropriate }\end{array}$ & $3(1)$ \\
\hline Number of PBL should be increased more than the lecture classes. & $2(1)$ \\
\hline $\begin{array}{l}\text { Lectures are more informative than PBL for particular topic. } \\
\text { Lectures are more useful than PBL in solving multiple choice } \\
\text { questions (MCQs) }\end{array}$ & $3(1)$ \\
\hline \begin{tabular}{l} 
Lectures are more useful than PBL in writing essay questions. \\
\hline $\begin{array}{l}\text { Lecture is more helpful than PBL in stimulating further reading of } \\
\text { text books. }\end{array}$
\end{tabular} & $3(1)$ \\
\hline \begin{tabular}{l} 
PBL exercises make subject more understandable than lectures. \\
\hline Retaining ability is more in PBL exercises compared to lectures.
\end{tabular} & $4(2)$ \\
\hline $\begin{array}{l}\text { PBL are more helpful in choosing rational drugs for prescription then } \\
\text { lecturers }\end{array}$ & $4(1)$ \\
\hline $\begin{array}{l}\text { PBL exercises are more useful than lectures in future clinical } \\
\text { practice. }\end{array}$ & $4(2)$ \\
\hline
\end{tabular}

\subsection{Student Perception on General Information on LBL and PBL (Table 2)}

Majority of student agreed with Lecture is essential before PBL for more understanding particular topic. Students want to increase number of lectures and PBL but number of PBL should not be more than lectures for this curriculum, it may be due to they are familiar with PBL in every chapter of pharmacology. 
Table 2: Student perception on general information on LBL and PBL

\begin{tabular}{|l|c|c|c|c|}
\hline \multicolumn{1}{|c|}{ Statements } & $\begin{array}{c}\text { Disagree } \\
(\mathbf{n}) \%\end{array}$ & $\begin{array}{c}\text { Neutral } \\
(\mathbf{n}) \%\end{array}$ & $\begin{array}{c}\text { Agree } \\
\text { (n)\% }\end{array}$ & $\begin{array}{c}\text { Strongly Agree } \\
\text { (n)\% }\end{array}$ \\
\hline $\begin{array}{l}\text { Lecture is essential before PBL for } \\
\text { understanding particular topic. }\end{array}$ & $(9) 3.6$ & $(4) 8.2$ & $(49) 44.5$ & $(48) 43.6$ \\
\hline $\begin{array}{l}\text { Number of lectures and PBL in the } \\
\text { current curriculum is appropriate }\end{array}$ & $(42) 38.2$ & $(30) 27.3$ & (36) 32.7 & (2) 1.8 \\
\hline $\begin{array}{l}\text { Number of PBL should be increased } \\
\text { more than the lecture classes }\end{array}$ & $(61) 55.5$ & $(33) 30$ & $(8) 7.3$ & (8) 7.3 \\
\hline
\end{tabular}

\subsection{Student Perception on LBL (Table 3)}

Table 3: Student perception on LBL

\begin{tabular}{|l|l|l|l|l|l|}
\hline \multicolumn{1}{|c|}{ Statements } & $\begin{array}{c}\text { Strongly } \\
\text { disagree } \\
(\mathbf{n}) \%\end{array}$ & $\begin{array}{c}\text { Disagree } \\
\text { (n) } \%\end{array}$ & $\begin{array}{c}\text { Neutral } \\
\text { (n)\% }\end{array}$ & $\begin{array}{c}\text { Agree } \\
\text { (n)\% }\end{array}$ & $\begin{array}{c}\text { Strongly } \\
\text { Agree } \\
\text { (n)\% }\end{array}$ \\
\hline $\begin{array}{l}\text { Lectures are more informative } \\
\text { than PBL for particular topic. }\end{array}$ & $\begin{array}{l}(6) 5.5 \\
(44) 40\end{array}$ & $(23) 20.9$ & $(35) 31.5$ & $(2) 1.8$ \\
\hline $\begin{array}{l}\text { Lectures are more useful than } \\
\text { PBL in solving multiple choice } \\
\text { questions (MCQs) }\end{array}$ & $(2) 1.8$ & $(25) 22.7$ & $(32) 20.1$ & $(45) 40-9$ & $(6) 5.5$ \\
\hline $\begin{array}{l}\text { Lectures are more useful than } \\
\text { PBL in writing essay questions. }\end{array}$ & $(5) 4.5$ & $(20) 18.2$ & $(38) 34.5$ & $(36) 32.7$ & $(11) 10$ \\
\hline $\begin{array}{l}\text { Lecture is more helpful than PBL } \\
\text { in stimulating further reading of } \\
\text { text books. }\end{array}$ & $(20) 18.2$ & $(15) 46.4$ & $(22) 20$ & (17) 15.5 & $(0) 0$ \\
\hline
\end{tabular}

In this study majority of student are disagreed with the statement lectures are more informative than PBL for particular topic and lecture are useful for solving MCQ is agreed by $51 \%$ of the students. About $42 \%$ of students agreed with Lectures are more useful than PBL in writing essay questions. Majority of student disagreed on lecture is more helpful than PBL in stimulating further reading of text books.

\subsection{Student Perception on PBL (Table 4)}

In this study majority of students agreed with PBL which makes subject more understandable, improve retaining ability, helpful in choosing rational drug prescribing and strongly agreed that it is more useful for future clinical practice than LBL. 


\begin{tabular}{|l|l|l|l|l|l|}
\hline \multicolumn{7}{|c|}{ Table 4: Student Perception on PBL } \\
\hline \multicolumn{1}{|c|}{ Statements } & $\begin{array}{c}\text { Strongly } \\
\text { disagree } \\
\text { (n) \% }\end{array}$ & $\begin{array}{c}\text { Disagree } \\
\text { (n) \% }\end{array}$ & $\begin{array}{c}\text { Neutral } \\
\text { (n) \% }\end{array}$ & $\begin{array}{c}\text { Agree } \\
\text { (n)\% } \%\end{array}$ & $\begin{array}{c}\text { Strongly } \\
\text { Agree } \\
\text { (n)\% }\end{array}$ \\
\hline $\begin{array}{l}\text { PBL exercises make subject } \\
\text { more understandable than } \\
\text { lectures. }\end{array}$ & $(2) 1.8$ & $(10) 9.1$ & $(25) 22.7$ & $(39) 35.5$ & $(34) 30.9$ \\
\hline $\begin{array}{l}\text { Retaining ability is more in } \\
\text { PBL exercises compared to } \\
\text { lectures. }\end{array}$ & $(0) 0$ & $(6) 5.5$ & $(18) 16.4$ & (59) 53.6 & (27) 24.5 \\
\hline $\begin{array}{l}\text { Compared to lectures, PBL are } \\
\text { more helpful in choosing } \\
\text { rational drugs for prescription. }\end{array}$ & $(0) 0$ & $(18) 16.4$ & $(14) 12.7$ & (55) 50 & (23) 20.9 \\
\hline $\begin{array}{l}\text { PBL exercises are more useful } \\
\text { than lectures in future clinical } \\
\text { practice. }\end{array}$ & $(0) 0$ & $(12) 10.9$ & $(31) 28.2$ & (25) 22.7 & (42) 38.2 \\
\hline
\end{tabular}

\section{Discussion}

In this questionnaire study student perception towards PBL was significantly higher 3.863 than LBL, i.e. 2.920, which was found to be statistically significant $(\mathrm{p}<0.05)$ showing student like PBL than LBL. They agreed that PBL stimulates their interest, improve retention of knowledge which helps in solving questions rationally and help to apply knowledge to understand and integrating basics with clinical sciences. Similar study had been done by Mohammad Imran ET $\mathrm{al}^{8}$ in 2015, the mean score was 3.80 with PBL and 2.84 with LBL, indicate PBL is useful over LBL. However further studies involving more number of student are warranted in order to generate stronger evidence on this tool for improving medical education setups.

A Similar type of study had done by Lalit Mohan et al $^{9}$ on 2014 in India, which shows total score (mean \pm standard deviation) for the questions numbered 4-7 related to LBL was 3.239 \pm 0.051 , and that of the questions numbered 8-11 related to PBL was 4.064 \pm 0.056 , indicate PBL is useful than LBL.

\section{Conclusion}

The current study was to compare the effectiveness and to assess perception of PBL and LBL in conveying the medical facts in pharmacology of second year medical students of Nepalgunj Medical College, it shows, students had more positive perception on teaching and learning, knowledge and skills, outcomes of their course materials and satisfaction with PBL compared to the LBL. In PBL, Student analyses the problem through self-directed efforts, solves the given problem by applying his knowledge and skills followed later by group discussions acquires knowledge and develops skills with adequate infrastructure, trained faculty, well-equipped library and internet facility which is always superior than didactic lectures. 


\section{Acknowledgement}

We acknowledge second year MBBS students of 2015 batch of NGMC for participating in this project.

\section{References}

[1] Sudha J. Graduate training programmes in pharmacology in India. Health Adm. 2006; 19 (1):8891.

[2] Mohan L, Shankar PR, Kamath A, Manish MS, Eesha BR. Students' attitudes towards the use of audio visual aids during didactic lectures in pharmacology. J Clin Diagn Res. 2010; 4 (6):3363-8.

[3] Jai Krishna, Singh A, Goel S, Gupta A, Sharma P, Mirza RUB, Singh AK, Surana A, Chitti Babu G. Students' current perceptions and feedback on teaching and learning Pharmacology from an evolving medical school. IAIM, 2015; 2(7): 99-104.

[4] Tisonova J, Hudec R, Szalayova A, Bozekova L, Wawruch M, Lassanova M, et al. Experience with problem oriented teaching in pharmacology. Bratisl Lek Listy. 2005; 106 (2):83-7.

[5] Wood DF. ABC of learning and teaching in medicine. Problem based learning. BMJ 2003; 326 (7384):328-30.

[6] Ghosh S, Dawka V. Combination of didactic lecture with problem-based learning sessions in physiology teaching in a developing medical college in Nepal. Adv Physiol Educ. 2000; 24 (1):812.

[7] Shankar PR, Dubey AK, Mishra P, Upadhyay D, Subish P, Deshpande PY. Student feedback on problem stimulated learning in pharmacology: a questionnaire based study. Pharm Educ. 2004; 4 (2):51-6.

[8] Imran M, Shamsi S, Singh A,Goel S, Sharma P, Panesar S. Problem based learning versus lecturer based learning in pharmacology in a junior doctor teaching program: a crossover study from northen India. Int.J.Res.Med Sci 2015;3:326-9

[9] Mohan L, Shenoy S, Eesha BR, Anoopkishore, Bairy KL, Patil N. Students' attitude toward didactic lecture versus problem-based learning in pharmacology: a questionnaire based study. Int J Basic Clin Pharmacol, 2014; 3:619-22. doi: 10.5455/2319-2003.ijbcp20140810

\footnotetext{
*Corresponding author.

E-mail address: drddhami@gmail.com
} 